\title{
The Role of Financial Instruments in Reducing Exchange Rate Risk
}

PhDc. Vlora Berisha

\author{
University “Haxhi Zeka”, Kosovo, vlora.berisha@unhz.eu
}

\author{
Dr. Rrustem Asllanaj
}

University of Prishtina "Hasan Prishtina”, Kosovo.

\author{
PhDc. Albulena Shala
}

University of Prishtina "Hasan Prishtina”, Kosovo, albulena.shala@hotmail.com

Doi:10.5901/ajis.2014.v3n2p371

\begin{abstract}
Companies that transact in different currencies face financial risk because of unpredictable exchange rate fluctuations. Exchange rate risk constitutes one of the most common forms of risk that firms in the international arena encounter and, in recent years, the management of this risk has become one of the key factors in overall financial management. Measuring and managing exchange rate risk exposure is important for reducing a firm's vulnerabilities from major exchange rate movements, which could adversely affect profit margins and the value of assets. The main purpose of this paper is to show the role of derivatives in reducing exchange rate risk. This paper treats the nature of these financial instruments and shows how they can be used to manage foreign exchange risk or enter into speculative positions of currencies movements.
\end{abstract}

Keywords: foreign exchange risk; hedging; international trade; risk management; forward and future contracts

\section{Introduction}

Today, the economic environment in which most firms operate is highly volatile and uncertain. One of the main factors effecting this process is the increasing market globalization and internationalization, which is reflected in increased exchange, interest, inflation rates fluctuations as well as in high competition, demand levels etc. Big multinational companies are particularly exposed to exchange rate fluctuation; therefore, special attention should be paid to exchange rate management.

Exchange rate risk management is an integral part in every firm's decisions about foreign currency exposure (Allayannis, Ihrig, and Weston, 2001). Currency risk hedging strategies entail eliminating or reducing this risk, and require understanding of both the ways that the exchange rate risk could affect the operations of economic agents and techniques to deal with the consequent risk implications (Barton, Shenkir, and Walker, 2002). Selecting the appropriate hedging strategy is often a daunting task due to the complexities involved in measuring accurately current risk exposure and deciding on the appropriate degree of risk exposure that ought to be covered. The need for currency risk management started to arise after the break down of the Bretton Woods system and the end of the U.S. dollar peg to gold in 1973 (Papaioannou, 2001).

In recent years science and financial practices have established and perfected the activity that in international language is called hedging. Security and risk reduction through hedging is the most common form used in practice. Most businesses use hedging not to get money, but to reduce financial risk.

The remainder of this paper is organized as follows: Section 2 lists the methodology of the study. Section 3 and 4 gives a short overview of the empirical literature on exchange rate exposure management. Section 5 presents the conclusion.

\section{Research methodology}

The methodology employed in this paper consists of the following phases: 
1. The problem that is identified on the research of the role of financial instruments in reducing the risk of exchange rate.

2. The elaborate plan of research which is therefore also collected literature bibliography is set to be used.

3. The defined structure and sections of the paper.

4. The paper discussed on the structure based on the knowledge gained through the qualitative data obtained mainly from books, articles, studies, and Internet sources.

\section{Literature Review}

Review of the literature noted that financial instruments are required to manage security risk against exchange rate fluctuations. Various authors, after thorough research and consideration of alternative courses of action, have reached the conclusion that in most cases financial instruments are necessary to minimize negative effects caused by exchange rate changes.

According to ISDA ${ }^{1}$ Survey in 2009 , over $94 \%$ of the World's largest companies use derivatives to help manage financial risk.

The survey found that the use of derivatives is common to companies worldwide: among the ten countries with the largest number of (Fortune) 500 companies surveyed, all companies based in Canada, France, Great Britain, Japan and The Netherlands report using derivatives, while 97 percent of German companies and 92 percent of US companies report using derivatives. Companies in South Korea and China were least likely to report using derivatives, but 87 percent of Korean companies and 62 percent of Chinese companies nonetheless did report using these instruments.

Author Björn Döhring (2008), in his paper "Hedging and Invoicing Strategies to Reduce Exchange Rate Exposure: a Euro-Area Perspective", discussed how domestic-currency invoicing and hedging allow internationally active firms to reduce their exposure to exchange rate variations. The paper described how the euro-area exporters make ample use of instruments at hand to limit the adverse impact of euro appreciation.

Authors, Victor Popov and Yann Stutuzmman (2003), in their research "How Is Foreign Exchange Risk Managed?An empirical Study to Two Swiss Companies", found significant differences in foreign exchange risk management policies, notably in the choice of the type of exposure to cover and in the hedging instruments used. Each company that they studied had a different approach to foreign exchange risk that was based upon its industry, trade volumes, geographical markets, market power, treasurer's opinion. They conclude that in order to develop a good FX risk management policy, a firm should know the level of risk for all currencies and adapt its policy to the knowledge of the managers regarding the instruments used.

Author, Anuradha Sivakumar (2007), in his research "Corporate Hedging for Foreign Exchange Risk in India" concluded that forwards and options are preferred as short term hedging instruments while swaps are preferred as long term hedging instruments.

\section{Overview - Financial Instruments and Exchange Rate Risk}

Most companies hedge risk - that is, they take actions to mitigate or offset the risks that arise from their activities. For financial risk - such as interest rate risk, currency risk, equity price risk and commodity price risk - such hedging often involves the use of derivatives.

Foreign exchange $(F X)$ risk management has become increasingly important since the abolishment of the fixed exchange rate system of Bretton Woods in 1976. This system was replaced by a floating rates system in which the price of currencies is determined by supply and demand of money (Victor Popov and Yan Stutzmann, 2003). Given the frequent changes of supply and demand influenced by numerous external factors, this new system is responsible for currency fluctuations. These fluctuations expose companies to a foreign exchange risk. Moreover, economies are getting more and more open with international trading constantly increasing and companies become as a consequence more exposed to foreign exchange rate fluctuations.

The exchange rate exposure has three different types in general: translation exposure, transaction exposure and economic exposure (Eiteman, Stronehill and Moffett, 2004). 


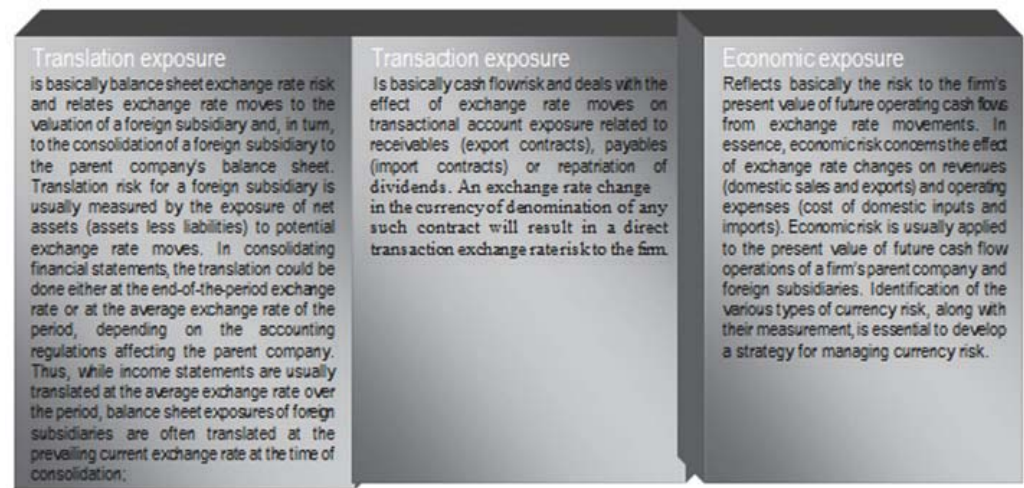

Figure 1. Types of exchange rate exposure Source: (Authors)

Figure No.2 (Eiteman 1995, p. 186) gives us a clear picture of how different kinds of risk are associated with the firms' business transactions, based on the "life span" of the firm's transaction from the seller's point of view.

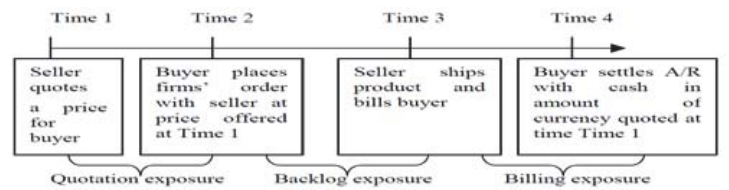

Figure 2. Firm's transaction life span. Source: (Eiteman)

The firm is already exposed to risk, in terms of quotation risk, before this particular business transaction begins. Quotation risk exposure is created at the moment Time 1, when the seller quotes the price, for the buyer is presented in written or verbal form. In the case of the unfavorable/favorable exchange rate change, sellers' inflows in the home currency might decrease/increase. The other important point is the competitors' price level, which might change as well. Both these factors might cause the tender cancellation risk. The tender price might be changed before the contract is signed resulting in a cancellation of the tender, and anticipated foreign currency inflows. This risk is usually called antenatal risk, which may not be reflected in the firm's accounting numbers. At this moment, the exposure will only be estimation; neither the size, nor the time of the exposure may be known at this time. If the price, and all the other transaction's conditions, fit the buyer, they will then set an order to the seller at the price agreed at Time 1. At that moment (Time 2) the backlog exposure appears and this will last until the moment when the seller ships the product to the buyer (Time 3 ). The risk is not usually shown at this stage in accounting numbers, but the firm already starts to include lots of costs and funds in order to generate that product. Thus, the later period's risk may influence the firm's future cash flow. Then, coming up to Time 3 , which is usually the point in time when most firms begin appropriate accounting records, this becomes billing exposure, which means that the customer may become insolvent or even become bankruptcy. He will then not be able to fulfill the contract condition causing the seller's expected income to go into uncertainty. That risk is usually called insolvency risk or credit risk, and will last until the final payment for that particular transaction in the specific foreign currency be made (Eiteman, Stonehill and Moffett, 1997).

\subsection{Currency Volatility}

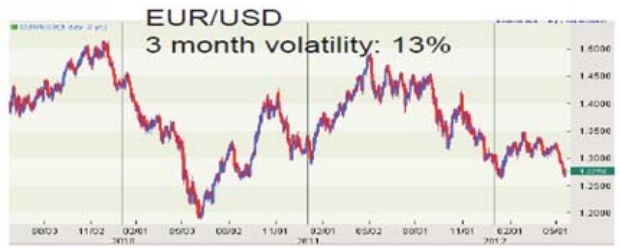

Figure 3. Currency volatility. Source: (Ahamed Kameel Mydin Meera) 
"Once every 100 years" events dramatically affected exchange rates: (Alpa Dhanani, 2002)

- 1998 Asian Tiger meltdown

- 1998 Russian devaluation and default, LTCM bailout

- 2001 September 11

- 2008 Icesave bank failure

- 2008 Lehman Bros/AIG

- 2010 Greek bailout \#1

- 2010 Ireland bailout (and subsequent rejection)

- 2011 Japan tsunami/nuclear reactor disaster, PIIGS debt, US credit de-rating

- 2012 Greek Euro exit? (and waiting on War: Iran/Israel, Syria; Debt crisis: Portugal/Spain

Currency risk can prove highly problematic for our businesses. Currency risk involves the foreign currency payables or receivables generated as a result of contracts the company has signed (or will sign). It is the risk that the currency wills fluctuate in a way that hurts the company, in that it will have to convert the foreign currency under terms that are not as good as originally budgeted. This is currency transaction risk.

- For an importer: the risk that the foreign currency will appreciate

- For an exporter: the risk that the foreign currency will depreciate

"Currency risk can be substantial but, thankfully, there are many ways to manage it." Desjardins

\subsection{Exposure managements strategies}

The risk management decision is the final phase of a 3-step process. The first step is to recognize if there is an exposure, the second is to measure it, and the third is to decide whether, and in which way, to manage it (Gregory J.Millman 1998).

For some companies, managing foreign exchange risk may seem too complex, costly or time-consuming. Others may not know about hedging instruments and techniques or believe that hedging is a speculative activity. Yet companies that choose not to manage foreign exchange risk may be assuming that exchange rates will remain at their present levels or move in a direction that will be favourable to the company - something that closely resembles speculation (Export Development Canada, 2010).

Numerous studies have found that managing this risk can successfully reduce your company's foreign exchange exposure. Managing foreign exchange risk provides the following benefits to many companies:

- minimize the effects of exchange rate movements on profit margins

- increase the predictability of future cash flows

- eliminate the need to accurately forecast the future direction of exchange rates

- facilitate the pricing of products sold on export markets

- protect, temporarily, a company's competitiveness if the value of the Canadian dollar rises (thereby buying time for the company to improve productivity)

\subsection{Tactics and Strategies for Reducing Foreign Exchange Risk}

The foreign exchange management involves a long decisional process which is synthetically presented below:

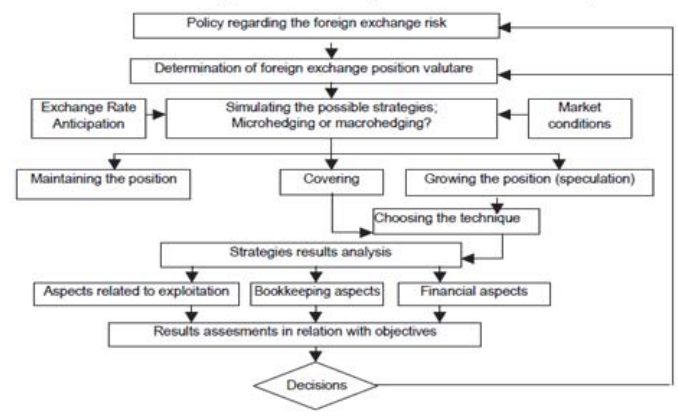

Figure 4. Foreign management decision process. Source: (Florentina-Olivia Bãlu) 


\subsubsection{Reducing Transaction and Translation Exposure}

Future currency exchange contracts (called "buying forward") and netting currency transactions are important sources of insurance against the short-term effects of foreign exchange exposure. Buying forward involves a currency contract for future sale or purchase of a foreign currency at a predefined exchange rate rather than the market rate at the time of the transaction. Terms of these forward contracts are set by the forward market itself and will vary with expectations of currency movements and the demand and supply of the currency transaction requests. The forward contracts may be firm commitments for transactions or may be options in which the purchaser can decide at the time of maturation whether or not to exercise the future contract. Future options have the advantage that favorable foreign exchange movements might result in extra profits, but the options will normally have a corresponding charge. Firms can also reduce their foreign exchange exposure through managing the timing of payables and receivables. A firm might collect and pay early or late depending on expected exchange rate movements. This timing involves accelerating payments from weak-currency to strong-currency countries and delaying inflows from strong-currency to weak-currency countries (Prashant Kapila and Chris Hendrickson, 2001)

\subsubsection{Reducing Economic Exposure}

Reducing economic exposure requires strategic choices that go beyond the realm of financial management. The key to reducing economic exposure is to distribute the firm's productive assets to various locations so the firm's long-term financial well-being is not severely affected by adverse changes in exchange rates.

\subsection{Natural hedging}

The objective of natural hedging is to reduce the difference between receipts and payments in a given foreign currency. For example, a Canadian manufacturer exports to the United States and expects to collect US\$5 million over the next year. If it expects to make payments of US $\$ 500,000$ during that time, the company's forecasted exposure to the US dollar is US $\$ 4.5$ million (assuming it holds no U.S. dollars in a bank account at present).

To reduce this exposure, the company may decide to borrow US\$1 million and to increase its procurement from American suppliers by US $\$ 1.5$ million. This reduces the company's exposure to US $\$ 2$ million. Alternatively, the company could decide to build or buy a production facility in the United States to eliminate most of the transaction exposure.

Natural hedging can be effective at reducing a company's foreign exchange risk but it can take time to implement natural hedges (e.g. finding new suppliers in another country) and these solutions often constitute long-term commitments (e.g. borrowing in U.S. dollars) (EDC, 2010).

\subsection{The foreign exchange markets}

An American company that imports goods from France may need to buy euros to pay for the purchase. An American company exporting to France may receive euros, which it sells in exchange for dollars. Both firms make use of the foreign exchange market. The foreign exchange market has no central marketplace. Business is conducted electronically. The principal dealers are the larger commercial banks and investment banks. A corporation that wants to buy or sell currency usually does so through a commercial bank. Turnover in the foreign exchange market is huge. In London in $2007 \$ 1,359$ billion of currency changed hands each day. That is equivalent to an annual turnover of about $\$ 340$ trillion $(\$ 340,000,000,000,000)$. New York and Tokyo together accounted for a further $\$ 902$ billion of turnover per day (Brealey, Mayers and Allen, 2010). 
Table 1. Spot and forward exchange rates, July 24, 2009.

\begin{tabular}{|c|c|c|c|c|}
\hline & \multirow[b]{2}{*}{ Spot Rate* } & \multicolumn{3}{|c|}{ Forward Rate } \\
\hline & & 1 Month & 3 Month & 1 Year \\
\hline \multicolumn{5}{|l|}{ Europe: } \\
\hline Euro & 1.4201 & 1.4201 & 1.4200 & 1.4207 \\
\hline Norway (krone) & 6.2452 & 6.2502 & 6.2603 & 6.3007 \\
\hline Sweden (krona) & 7.4533 & 7.4523 & 7.4502 & 7.4313 \\
\hline Switzerland (tranc) & 1.0723 & 1.0719 & 1.0711 & 1.0643 \\
\hline United Kingdom (pound) & 1.6414 & 1.6413 & 1.6411 & 1.6396 \\
\hline \multicolumn{5}{|l|}{ Americas: } \\
\hline Canada (dollar) & 1.0808 & 1.0807 & 1.0804 & 1.0801 \\
\hline Mexico (peso) & 13.2155 & 13.2705 & 13.3805 & 13.8891 \\
\hline \multicolumn{5}{|l|}{ Pacific/Middle East/Atricax } \\
\hline Hong Kong (dollar) & 7.7501 & 7.7480 & 7.7437 & 7.7311 \\
\hline Japan (yen) & 94.7050 & 94.6780 & 94.6161 & 94.0870 \\
\hline South Africa (rand) & 7.7840 & 7.8330 & 7.9263 & 8.3283 \\
\hline South Korea (won) & 1249.55 & 1249.10 & 1247.65 & 1241.05 \\
\hline
\end{tabular}

* Rates show the number of units of foreign currency per U.S. dollar, except for the euro and the U.K. pound, which show the number of U.S. dollars per unit of foreign currency.

Source: Financial Times.

Table 1 is adapted from the table of exchange rates in the Financial Times. Exchange rates are generally expressed in terms of the number of units of the foreign currency needed to buy one U.S. dollar. This is termed an indirect quote. In the first column of Table 1, the indirect quote for the Mexican peso shows that you can buy 13.2155 pesos for $\$ 1$. This is often written as peso $13.2155 / \$$. A direct exchange rate quote states how many dollars you can buy for one unit of foreign currency. The euro and the British pound sterling are usually shown as direct quotes. For example, Table 27.1 shows that $£ 1$ is equivalent to $\$ 1.6414$ or, more concisely, $\$ 1.6414 / £$. If $£ 1$ buys $\$ 1.6414$, then $\$ 1$ must buy $1 / 1.6414 \_£ .6092$. Thus the indirect quote for the pound is $£ .6092 / \$$. The exchange rates in the first column of Table 27.1 are the prices of currency for immediate delivery. These are known as spot rates of exchange. The spot rate for the peso is peso $13.2155 / \$$, and the spot rate for the pound is $\$ 1.6414 / \mathbf{E}$. In addition to the spot exchange market, there is a forward market. In the forward market you buy and sell currency for future delivery. If you know that you are going to pay out or receive foreign currency at some future date, you can insure yourself against loss by buying or selling forward. Thus, if you need one million pesos in three months, you can enter into a three-month forward contract. The forward rate on this contract is the price you agree to pay in three months when the one million pesos are delivered. If you look again at Table 1 , you will see that the three-month forward rate for the peso is quoted at peso $13.3805 / \$$. If you buy pesos for three months' delivery, you get more pesos for your dollar than if you buy them spot. In this case the peso is said to trade at a forward discount relative to the dollar, because forward pesos are cheaper than spot ones. Expressed as an annual rate, the forward discount is:

$$
4 \times\left(\frac{13.2155}{13.3805}-1\right)=-.049, \text { or }-4.9 \%
$$

You could also say that the dollar was selling at a forward premium. A forward purchase or sale is a made-tomeasure transaction between you and the bank. It can be for any currency, any amount, and any delivery day. You could buy, say, 99,999 Vietnamese dong or Haitian gourdes for a year and a day forward as long as you can find a bank ready to deal. Most forward transactions are for six months or less, but the long term currency swaps are equivalent to a bundle of forward transactions. When firms want to enter into long-term forward contracts, they usually do so through a currency swap. There is also an organized market for currency for future delivery known as the currency futures market. Futures contracts are highly standardized; they are for specified amounts and for a limited choice of delivery dates. When you buy a forward or futures contract, you are committed to taking delivery of the currency. As an alternative, you can take out an option to buy or sell currency in the future at a price that is fixed today. Made-to-measure currency options can be bought from the major banks, and standardized options are traded on the options exchanges (Brealey, Mayers and Allen, 2010).

\section{Concluding Remarks}

Measuring and managing currency risk exposure are important functions in reducing a firm's vulnerabilities from major exchange rate movements. The efficient management of this risk is essential for the survival of a company and any business that is exposed to such a risk should ensure that it is fully prepared to manage it. Old standbys and recent breakthroughs in the area of financial risk management can remove much of the risk from currency rate movements. The range of such products is huge, with increasingly sophisticated techniques constantly being added. Prudent management 
of currency risk has been increasingly mandated by corporate boards, especially after the currency-crisis episodes of the last decade and the consequent heightened international attention on accounting and balance sheet risks. In managing currency risk, multinational firms utilize different hedging strategies depending on the specific type of currency risk. These strategies have become increasingly complicated as they try to address simultaneously transaction, translation and economic risks.

\section{Recommendations}

Firms need to look at instituting a sound risk management system and also need to formulate their hedging strategy that suits their specific firm characteristics and exposures.

Many companies are intimidated by currency risk and avoid international trade so that they do not have to deal with it. There are many strategies and products for protecting against currency risk. Currency risk should not be an obstacle to international trade.

In short, here are the main things to remember:

- Currency risk is a reality for many businesses.

- Currency risk can be substantial, putting the company's survival at risk.

- Currency risk materializes well before invoicing.

- The company should focus on its operations (its area of expertise) and protect itself from risks in which it has no expertise (currency risk).

- There are many products and strategies for eliminating or reducing currency risk

Each failure in any area of risk management leads to financial loss and in extreme cases can even result in bankruptcy. Therefore, it is clear that without proper risk management enterprises can fail in a very short time.

\section{References}

Allayannis, G. and Ofek, E., 2001. "Exchange Rate Exposure, Hedging, and the Use of Foreign Currency Derivatives." Journal of International Money and Finance, 20 (2), page 273-296.

Alpa Dhanani, 2002. "Foreign exchange risk management, British Accounting review. page 20.

Anuradha Sivakumar (2007), " Corporate hedging for exchange rate in India" Paper work, pg.8

Anthony J.H. The international of Stock option market trading volume, Data journal of Finance 1988:43 no. 4 page. 949-960

Brealey\&Mayers\&Allan, "Principles of Corporate Finance", tenth edition. Page. 676.

Björn Döhring (2008), "Hedging and Invoicing Strategies to Reduce Exchange Rate Exposure: a Euro Area Perspective ", Working paper , page $345-370$.

Eric Banks, "Alternative risk transfer". John Wiley, 2004. Page 34.

Florentina-Olivia Bãlu. (2005). "Foreign Exchange Risk in International Transactions" page .45.

Géczy, Minton and Schrand, 1997."Why firms use financial derivation" Financial Journal. page. 1324

Prashant Kapila and Chris Hendrickson.(2001) "Exchage rate risk management in international construction venetures". Page 5.

Viktor Popov dhe Yann Stutuzmman (2003), " How to manage exchange risk". Working paper, page 78- 98.

Vika Brucaite \& Shanhong Yan (2010). "Financial Risk Management -Case Studies with SKF and Elof Hansson". Page .80 
